NBER WORKING PAPER SERIES

\title{
INTERNATIONAL TAX REFORMS WITH FLEXIBLE PRICES
}

\author{
Assaf Razin \\ Efraim Sadka \\ Working Paper 24204 \\ http://www.nber.org/papers/w24204
}

\author{
NATIONAL BUREAU OF ECONOMIC RESEARCH \\ 1050 Massachusetts Avenue \\ Cambridge, MA 02138 \\ January 2018
}

The views expressed herein are those of the authors and do not necessarily reflect the views of the National Bureau of Economic Research.

NBER working papers are circulated for discussion and comment purposes. They have not been peer-reviewed or been subject to the review by the NBER Board of Directors that accompanies official NBER publications.

(C) 2018 by Assaf Razin and Efraim Sadka. All rights reserved. Short sections of text, not to exceed two paragraphs, may be quoted without explicit permission provided that full credit, including (c) notice, is given to the source. 
International Tax Reforms with Flexible Prices

Assaf Razin and Efraim Sadka

NBER Working Paper No. 24204

January 2018

JEL No. F0,G20,H2

\title{
ABSTRACT
}

The growing spread of globalization creates a genuine need for international tax reforms. In this we establish the neutrality of border-tax adjustments of the income tax; the welfare dominance of residence-based over source-based income taxation, albeit at the cost of a larger trade deficit; and the ineffectiveness of non-transitory border taxes as a means for reducing the trade deficit.

\author{
Assaf Razin \\ Eitan Berglas School of Economics \\ Tel Aviv University \\ Tel Aviv 69978 \\ ISRAEL \\ and Cornell University and CEPR \\ and also NBER \\ ar256@cornell.edu \\ Efraim Sadka \\ Tel Aviv University \\ Eitan Berglas School of Economics \\ P.O.B. 39040 \\ Ramat Aviv, Tel Aviv, 69978, ISRAEL \\ sadka@post.tau.ac.il
}




\section{Abstract}

The growing spread of globalization creates a genuine need for international tax reforms. In this we establish the neutrality of border-tax adjustments of the income tax; the welfare dominance of residence-based over source-based income taxation, albeit at the cost of a larger trade deficit; and the ineffectiveness of non-transitory border taxes as a means for reducing the trade deficit.

\section{Introduction}

The growing and continuous spread of globalization inevitably triggers a process of international tax reforms. One important aspect in this context is border-tax adjustments. The latter have received an even wider attention in view of recent proposals for tax reforms in the U.S.

Reforms are typically aimed at long-run restructuring of the economic landscape. Therefore, it is useful to analyze them in a long run setup, which ensues flexible rather than sticky prices ${ }^{3}$.

Typically, tax reforms have both efficiency and distribution implications. Nevertheless, the latter are not in the forefront of the issues considered here. As common in the literature, we therefor simplify by considering a representative consumer.

In this note we analyze the implications of border-tax adjustments in the income tax and of a shift from source-based to residence-based international income taxation, paying a special attention individual welfare and to the trade balance. In addition, we re-examine the effectiveness of border taxes as a means to reducing trade deficits.

\section{Income Taxation and Border-Tax Adjustment}

Border-tax adjustments of the income tax has received a growing public and academic attention since the introduction of the U.S. House Republican tax plan in June, 2016. In addition to replacing the ordinary corporate income tax with a cash-flow tax, it was proposed also to introduce border tax adjustments (à la VAT) according to which expenditures on imports are not deductible from taxable income, and export revenues are exempted ${ }^{4}$. We focus on the border-tax adjustments components of the plan and analyze its implication for the real exchange rate.

Consider a minimal Fisherian model that can serve to highlight our arguments and conclusions. Suppose there are only two periods and one composite, tradable good that can serve for present consumption $\left(c_{0}\right)$, future consumption $\left(c_{1}\right)$, investment (I), imports $(M)$ and exports $(X)$. There is a representative consumer and a representative producer. There is an initial endowment in the first period and none in the second. There is a flat income tax rate $(t)$ that applies to both individuals and businesses. As common in advance economies, the tax is based on the residence principle according to which residents (both individuals and businesses) are taxed on their world-wide income, irrespective of its origin - domestic or foreign ${ }^{5}$. As residents are taxed on their capital

\footnotetext{
${ }^{3}$ Early on, Berglas (1974) and recently Buiter (2017) analyze border-tax adjustments in the context of sticky prices.

${ }^{4}$ See a detailed analysis of the plan in Auerbach (2017) and Auerbach et al. (2017).

${ }^{5}$ See Frenkel, Razin and Sadka (1990 and 1991) for an analysis of the basic principles of international taxation.
} 
income at the same rate whether they invest at home or abroad, the domestic real interest rate in our small open economy is equal, by arbitrage, to the internationally given real interest rate $\left(r^{*}\right)$.

Suppose first that there are no border-tax adjustments. As expected in this standard model, the equilibrium is characterized by the standard marginality conditions: the marginal product of capital equals $r^{*}$ and the intertemporal marginal rate of substitution of future for present consumption equals $1+(1-t) r^{* 6}$. Note that the marginal rate of substitution (the absolute slope of the consumer's indifference curve) is lower than the absolute slope of the production possibilities frontier (in essence, we can say that there is inadequate domestic savings).

This equilibrium is illustrated in Figure 1.

\section{Future Consumption}

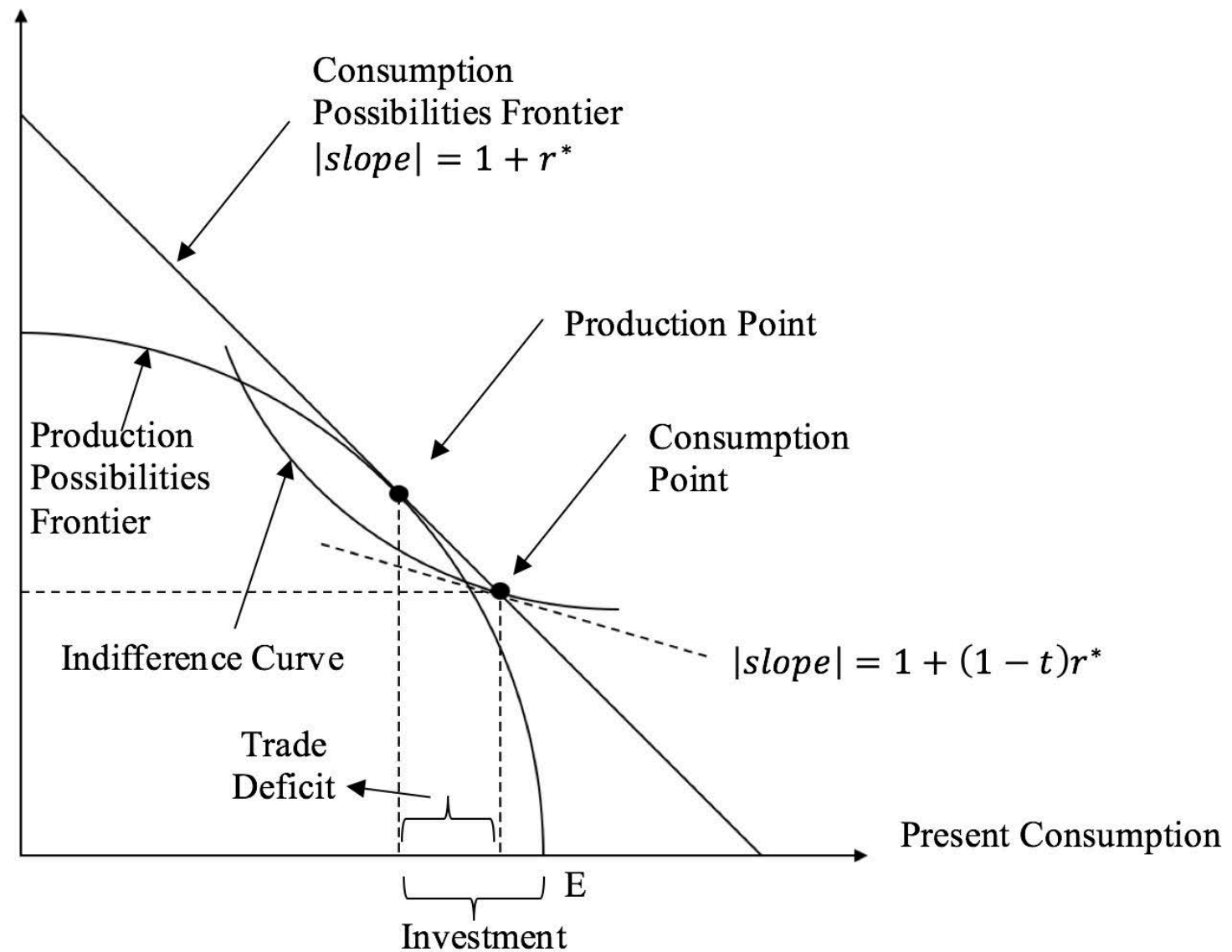

Figure 1: Residence-Based Taxation Allocation with or without Border-Tax Adjustments

Now, consider border-tax adjustments, where imports are not deductible, and exports are tax exempt. Suppose that the world price of the composite good is unity. Because imports are not deductible, the domestic price of the composite good must be grossed up to $\frac{1}{1-t}$ if imported, through

${ }^{6}$ This specification assumes for simplicity that capital does not depreciate. 
arbitrage. Similarly, because exports are exempted, the domestic price of the composite good will

be also grossed up to $\frac{1}{1-t}$, if exported. Thus, the consumer intertemporal relative price remains $1+$ $(1-t) r^{*}$ and the producer intertemporal relative price remains $1+r^{*}$. Hence, the equilibrium is characterized again by the same marginality conditions as before. This equilibrium is depicted in Figure 2, which re-depict also the former equilibrium for comparison.

Therefore border-tax adjustments have no effect on the equilibrium in this simple setup with no non-tradable goods. This establishes the neutrality of border-tax adjustments ${ }^{7}$.

\section{Reforming the Income Tax from the Source-Based to the Residence Principle}

Israel's tax system was by and large based on the source principle. That is, only income from domestic sources are subject to a tax, whereas foreign-source income is exempt. With the growing process of Globalization, especially in the capital field, Israel shifted to the residence principle in $2003^{8}$.

The equilibrium under the residence principle was already analyzed and depicted in the preceding section. Here we illustrate the equilibrium under the source principle and compare it to the residence equilibrium.

As foreign-source income is not taxed, whereas domestic-source income is taxed, it follows by arbitrage that the domestic real rate of interest will be grossed up to $\frac{r^{*}}{1-t}$. As a result, the source equilibrium will be characterized by the marginal product of capital being equal to $r^{*} /(1-t)$ and the intertemporal marginal rate of substitution of future for present consumption being equal to 1 $+\mathrm{r}^{*}$. That is, production is at a point, where the marginal product of capita is below the world real rate of interest (there is inadequate domestic investment). As a result, the consumption possibilities frontier shrinks; see figure 2 .

\footnotetext{
${ }^{7}$ The neutrality of border tax adjustment holds also under source-based taxation, and when there are non-traded goods.

${ }^{8}$ Israel's globalization process culminated in 2010 with the joining of the OECD group, see Razin (2018).
} 


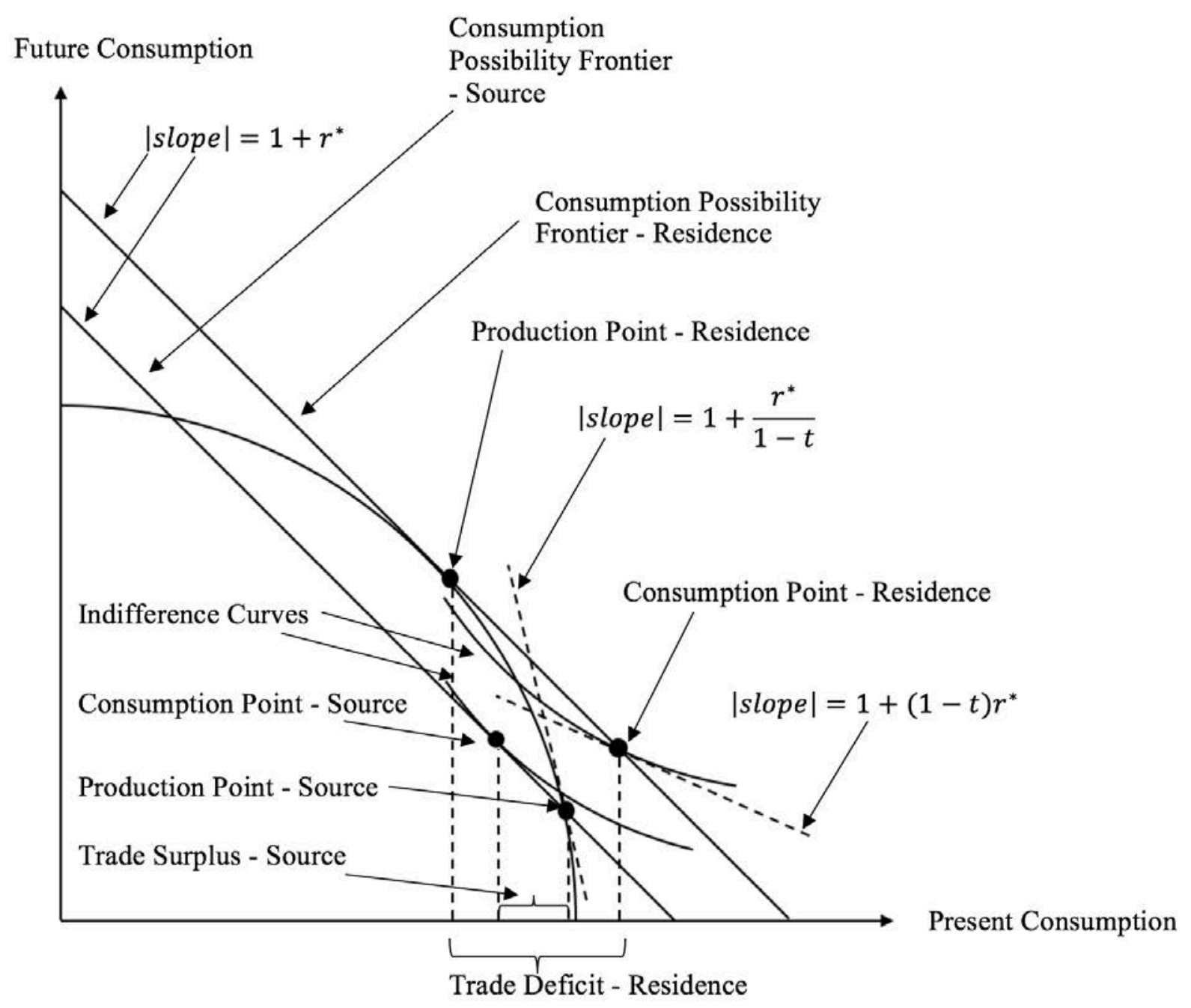

Figure 2: Source versus Residence-Based Taxation

Moving from a source-based to a residence-based taxation clearly enhances welfare ${ }^{9}$. Also, it worsens the trade deficit (in our example in Figure 2, a trade surplus turns into a trade deficit).

\section{Border Taxes and the Trade Balance}

So far, we did not have any border taxes (barriers to trade). Even the border-tax adjustments discussed in section 1 were shown to not amount to border taxes. In this section, we address the issue of border taxes.

${ }^{9}$ The reader familiar with the public economics literature will undoubtedly realize that this result is a variant of the Diamond-Mirrlees aggregate production efficiency theorem (1971); see also Frenkel, Razin and Sadka (1991). 
For Trump, NAFTA is "an economic disaster", because the United States has increased its trade deficit with Mexico from a \$1.6 billion surplus in 1993 (the year prior to NAFTA's implementation) to $\$ 63.2$ billion in 2016. In part, the US-Mexico trade balance reflected a weak peso after it was weakened by the uncertainty over the future of US-Mexico bilateral trade relations. To reverse it, Trump's solution is to abolish NAFTA.

Policy makers often justify export subsidies and import tariffs by their improving effects on the trade balance. On the other hand, in standard international trade theory, we teach the Lerner's (1936) Symmetry Theorem, according to which export taxes (rather than subsidies) and import tariffs have identical effects on resource allocation. In his analysis Lerner explicitly abstracted from intertemporal aspects. The apparent puzzle is resolved once a distinction is made between temporary and permanent trade taxes in an explicitly intertemporal model. Razin and Svensson (1983) show that only a temporary import tariff improves the trade balance, and only a temporary export tax deteriorates it. However, fully persistent import tariffs or export taxes have an identical effect on the trade balance, as in Lerner's Symmetry. Furthermore, to the first approximation, border taxes neither improve nor deteriorate the trade balance. The reason for this result is that temporary trade taxes, in contrast to permanent trade taxes, result in changes in intertemporal relative prices, and hence induce substitution between present and future goods. Therefore, they do affect savings and investment behavior.

\section{Conclusion}

In looking at residence treatment of companies, as opposed to individuals the issues are: (1) A US company may have shareholders who are not US resident individuals; and, (2) The US residencebased corporate tax is that company residence is endogenous, leading to corporate inversions. 


\section{References}

Auerbach Alan J. (2017), “Demystifying the Destination-Based Cash-Flow

Tax”, NBER working paper No. 23881.

Auerbach, Alan J., Michael P. Devereux, Michael Keen, and John Vella (2017), "DestinationBased Cash Flow Taxation." WP 17/01, Oxford University Centre for Business Taxation.

Berglas, Eitan (1974), “Devaluation, Monetary Policy and Border Tax Adjustment”, Canadian Journal of Economics, Vol. 7, no. 1, pp.1-11.

Buiter, Willem H. (2017), "Exchange Rate Implications of Border-Tax Adjustment Neutrality”, CEPR VOX, 22 March.

Diamond, Peter A., and James A. Mirrlees, (1971). “Optimal Taxation and Public Production,” American Economic Review, March and June, pp. 8-17 and pp. 261-178.

Frenkel, Jacob A., Assaf Razin, and Efraim Sadka (1990), “Basic Concepts of International Taxation”, NBEW WP 3540.

Frenkel, Jacob A., Assaf Razin, and Efraim Sadka (1991), International Taxation in an Integrated World, MIT Press.

Lerner, Abba (1936), “The symmetry between import and export taxes”. Economica 3, 306-313; also reprinted in R.E. Caves and H.G. Johnson, eds. (1968), Readings in International Economics (Allen and Unwin, London) 197-203.

Razin, Assaf, and Lars E.O. Svensson (1983), “Trade Taxes and the Current Account”, Economic Letter, 13 55-57

Razin Assaf (2018), Israel and the World Economy: The power of Globalization, MIT Press. 